\title{
村田沙耶香『コンビニ人間』
}

タイにおけるその翻訳と文化の受容をめぐって

Piyanuch WIRIYAENAWAT(ピヤヌット・ウィリヤエナワット:

Assistant Professor, Ph.D., Thammasat University)

图 piyanuchwiri@gmail.com

(タイ)タマサート大学日本語講座助教授。大阪大学て2014年「夏目漱石作品の研究一対照的に描かれる男性たちを中 心として一」で博士号取得。最近は日本近現代文学におけるジェンダーや日本文学における日本文化に対するタイ人 の異文化への理解について研究。主な研究としては論文(共著)「吉本ばなるの作品に対するタイ人日本語学習者の観点 —『満月』の場合—」(バンコク：Journal of the Faculty of Arts Silpakorn University, 2018)、(共著)「樋口一葉『十三夜』 における「鬼のイメージを通してタイ人日本語学習の異文化への理解をめぐって」(バンコク： Journal of Language and Culture, 2019)、「太宰治『ヴィヨンの妻』における「女給」のイメージとタイ人の「女給」との比較の場合」(バンコク： Journal of the Faculty of Arts Silpakorn University, 2020)など。

\section{A Study of the Thai Translation and Cultural Reception of Convenience Store Woman by Sayaka Murata}

This article examines the translation of Convenience Store Woman by Murata Sayaka, the original of which received the $155^{\text {th }}$ Akutagawa prize for Japanese literature. In addition, this article analyzes how the Thai general public and Thai Japanese-learners read this work. The book was warmly welcomed by Thai readers, and was one of the five bestselling books in Thailand between 2018 and 2019. Many Thai readers commented that this work centered around the issue of "normality" in modern society, and some of them had sympathy for the protagonist. The translator faced a problem in rendering culture-specific terms in Thai, and she employed transliteration and specification strategies to resolve it, which helped Thai readers to comprehend Japanese culture more vividly. Unlike Thai readers in general, Thai Japanese-learners focused on a wide range of dimensions of the book, including its portrayal of Japanese work habits and occupational culture, gender in Japanese society, "convenience store" culture, and the problem of sub-replacement fertility rates. For these reasons it seems inarguable that this book is a masterpiece that reflects the richness of Japanese culture and society.

Keywords Murata Sayaka(村田紗耶香), Convenience Store Woman(『コンビ 二人間』), Convenience store(コンビニ), Thai(タイ), Translation (翻訳) 


\section{1 はじめに}

村田紗耶香『コンビニ人間』は、2016年『文學界』の6月号に掲載後、文藝春秋社より同 じ年の7月27日に刊行された。第155回(2016年)に芥川龍之介賞を受賞した小説である。 本作品を執筆したきっかけについて、村田は次のように語っている。「最初は全く違 う、オタクの女の子が主人公の話を書いていたの。でも、『消滅世界』つていう、前に書 いた作品と被っているような気がしてきて。(略)たぶん、『しろいろの街の、その骨の 体温の』みたいなリアルに近い世界と、『殺人出産』たいなへんてこな世界をいつか融 合させたい気持ちがあったんだと思う」。また、村田自身も執筆業の傍ら週三回、コン ビニでのアルバイト店員をしていることで話題になった。『コンビニ人間』は人称独白 形式によって物語が展開し、以下のような粗筋である。36歳の未婚で、彼氏なしの主人 公である古倉恵子は、大学の時代から 18 年間、正規の就職をせず、コンビニ「スマイル マート日色町駅前」でアルバイトを続けていた。子供の頃から周りに少し奇妙がられる 子供だった古倉は、コンビニでの同僚の話し方や服装などを模倣したり、妹の助言を聞 くことによって、大学生になってようやく「普通」の人間らしく振る舞う方法を身に付け たと思っていた。コンビニのものを食べ、コンビニで働くことは、古倉に安心感をも たらしてくれた。そのような生活を続けていた時、婚活目的で新しく入って来た白羽と いう男性の出現によって、古倉の生活は変わってしまう。アルバイトをクビになった 白羽と再会後、古倉と白羽は周囲に「同棲」と解釈されるような奇妙な同居生活を始め る。そして、白羽に言われるままにコンビニの仕事を辞め、就活を始める。最後は、白 羽に送られて就職の面接に向かう途中たまたま立ち寄ったコンビニで、古倉はコンビニ 店員こそが自分の生きる道であることを意識させられた。そして、白羽と関係を解消 し、結局コンビニに復職することを決めた。

本作品の評価として、まず、芥川賞を受賞した時の評価を取り上げたい。「芥川賞選 評」では、奥泉光氏は「人は誰しも自分の言葉を喋り、自らの欲望に従って行動している ように見えて、じつはほかの誰かの言葉や欲望を模倣しているにすぎない——、こ のあたりの事情は数多の思索者によって論究されてきたわけだけれど、本作はこの人間 世界の実相を、世間の常識から外れた怪物的人物を主人公に据えることで、鮮やかに、 分かりやすく、かつ可笑しく描き出した」と述べている。（引用の下線は論者により付し たものである。以下同様。)更に、堀江敏幸氏は「指のささくれを一本ずつ抜いていくよ うな心理の詰め方が逆にユーモアを生み、異物を排除する正常さの暴力をあぶり出す。 読後に差し込む不思議な明るさに、強く引き寄せられた」と述べ、小川洋子氏は「社会的 異物である主人公を、人工的に正常化したコンビニの箱の中に立たせた時、外の世界に いる人々の怪しさが生々しく見えてくる。あるいは、明らかな奇人、白羽が主人公の部 屋で一緒に暮らすうち、思いがけず凡庸な正体を露呈してしまう。あやふやな境界を自 在に伸び縮みさせる、このあたりの展開を面白く読んだ」と評している。また、中村文 
則氏は本作品の文庫本の解説で以下のように述べている。「社会では、『普通』に生きる ことを(ものすごく面倒で厄介に)要求されるが、主人公はその『普通の人生』もマニュア ル化していると看破する」、文学的な質の高さだけでなく、生き難さを増す『普通圧力』 の社会に颯爽と登場した、まさに逆の意味で時代が生んだ小説でもある」など、『コンビ 二人間』は現代社会の問題を描いた作品であり、主人公の生き方を通して「普通」「正常」 とは何かを問う作品として読まれてきている。

そして、従来の先行研究を整理すると以下のように維められる。まず、村田の初期 作品から取り扱われる「性」のテーマについて、その推移に注目した論文を見てみたい。 矢野千晶氏 (2017) は村田の文壇デビューした作品である『授乳』から『コンビニ人間』に 至るまで描かれる「性」の問題と、主人公と他者との関係の変化を分析した。矢野氏は 「村田作品全体にいえるのは、男らしさ、女らしさというジェンダー的固定観念を破壊 しようとしていることである。男性優位社会や、異性愛主義、結婚や出産の強制など、 村田は現代を生きる誰もが当然と思い込んでいる常識に疑問を持ち、抗う。そして異常 を独自の解釈で正当化し、物語の中の人物だけでなく、読者をも納得させてしまう。正 常と異常とは、表裏一体である。「コンビニ人間」は、古倉のような他者や社会との関わ りを断ち切る人間が、異常者であることを曝し出しているのではない。むしろ、芥川賞 選考委員が古倉を「世間の常識から外れた」、「まともな人間」でないと決めつけている現 代社会に対して異常だと主張しているのではないか」と指摘している。

矢野氏の論考に似通った見解を示した飯田祐子氏 (2019) は本作品における「ジェン ダーとクイア」といら概念に重点を置き、「近未来的な社会を描いた作品では、性行為か ら生殖に至るジェンダー役割の組み替えや破戒がなされ、性別のない空間や、「「人間」 というアイデンティティを破棄する世界も描かれてきた」、『コンビニ人間』は、結婚や 家族や性欲欲望や愛などという制度的要素をすべて消去する、過激で不穏な寓意的存在 である」と論じている。また、橋本夏希氏 (2019)は『コンビニ人間』と、『殺人出産』吕及び 『マウス』との比較を行いながら、村田作品の変遷に焦点を当て、村田作品の中における 『コンビニ人間』の位置づけを考察した。橋本氏は「本作では普遍的な「普通」は存在しな いことを描きながらも、同時にく人間が社会に適応する上で従うべき規範はコミュニ ティごとに存在している〉という「普遍性」を提示することで、結果として社会の複雑な 構造を浮き彫りにしているのである」と結論付けている。つまり、『コンビニ人間』は村 田の初期作品から度々取り上げられている「ジェンダー的固定観念を破壊」する「性」の問 題を提示しつつ、他作品とは異なったリアルな世界を舞台とした、現代社会の「正常」あ るいは「普通」を問う作品だと言えよう。

次に、日本以外の国の反応や評価を見てみたい。本作品は芥川賞を受賞し、「時代が 生んだ小説でも」あるため、日本の読者のみならず、世界各国の多くの読者に迎えられ

1 2003年に第46回群像新人文学賞優秀賞受賞した作品である。

2 2014年に第14回センス・オブ・ジェンダー賞少子化対策特別賞を受賞した作品である。 
ている。作品は英語翻訳も含め現在約 30 の言語に翻訳されている3。アメリカでは 『Convenience Store Woman』というタイトルで刊行され、米雑誌『ザ・ニューヨーカー』 (The New Yorker)が選ぶ「The Best Books of 2018」にも選ばれている4。アメリカでは どのように本作品が受け入れられたかというと、渡辺由佳里氏はニューズウィーク (Newsweek)の日本版のサイトに「英語圏ではわかりにくい『コンビニ人間』の日本的背景」 という題目の下で、次のように述べている。「英語圏の読者にも、恵子に与えられてい る「社会に適合するプレッシャ一」に共感を覚え、惚れ込んでいる人はいる。(略) 日本社 会の閉塞感を実際に体験している日本人は、恵子が日常的に感じるプレッシャ一を作者 につぶさに説明してもらう必要はない。だが、日本社会を知らないアメリカ人読者が理 解するためには、もっと恵子の心理描写が必要になる」アメリカでこの作品がべストセ

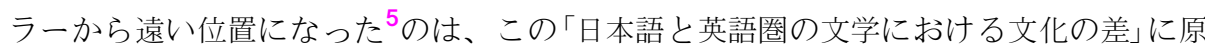
因があると言えよう。日本では出版直後から爆発的な売れ行きを示したものの、英語圈 であるアメリカではそうではなかったらしい。明らかに日米文化の違いが根底にあ り、日本以外の外国人の読者がどれぐらい作品を理解できるかということに疑問があ る。先程述べたように、英語以外にも『コンビニ人間』は約300言語に翻訳され、タイ語 翻訳もその中の一つに入っている。日本と同じアジア圏にあるタイでは、タイ人の読者 は『コンビニ人間』をどのように読むのだろう。本稿では、『コンビニ人間』のタイ語翻 訳を検討しながら、タイ人の一般の読者と日本語学習者の読者の作品への読み、文化受 容について明らかにしてみたい。

\section{2 タイにおける評判}

タイでの『コンビニ人間は』は日本での発表から2年後の2018年10月に、長年編集やラ イトノベルの翻訳に携わるパンウィモン・チターウィリヤクン氏によってタイ語に翻 訳され、出版された。日本語の原本は2017年に刊行された『コンビニ人間』文庫本であっ た。タイ語翻訳版はA5サイズで、表紙の外観を【図1】に示す。

3 例えば、中国語翻訳のタイトルは『人间便利店』、韓国語翻訳のタイトルは『편의점 인간』、フランス語翻訳 のタイトルは『LA FILLE DE LA SUPÉRETTE』、ドイツ語翻訳のタイトルは『DIE LADEN HÜTERIN』な どである。

4 他の8作品は次の通りである。(1)“Confessions of the FoX” by Jordy Rosenberg (2)“Ordinary People” by Diana Evans (3) "Small Fry" by Lisa Brennan-Jobs (4) "Florida" by Lauren Groff (5) "Kudos" by Rachel Cusk (6) "Freshwater" by Akwaeke Emezi (7) "Immigrant, Montana" by Amitava Kumar (8) "Asymmetry" by Lisa Halliday なお、英語翻訳は竹森ジニー氏が担当し、2018年6月12日、村田にとっては初の英訳作品として アメリカで刊行された。

5 アメリカにおけるConvenience Store Womanの売り上げについて、渡辺由佳里氏は更に次のように述べ た。「だが、発売から1カ月たった7月17日現在、『Convenience Store Woman』はアマゾンのハードカバー ランキングで4261位、有料キンドル版で7800位とベストセラーには程遠い位置にある。」また、売り上げ の低いもう一つの理由は「小説の長さと形式の問題もあるかもしれない」と渡辺氏は指摘した。 


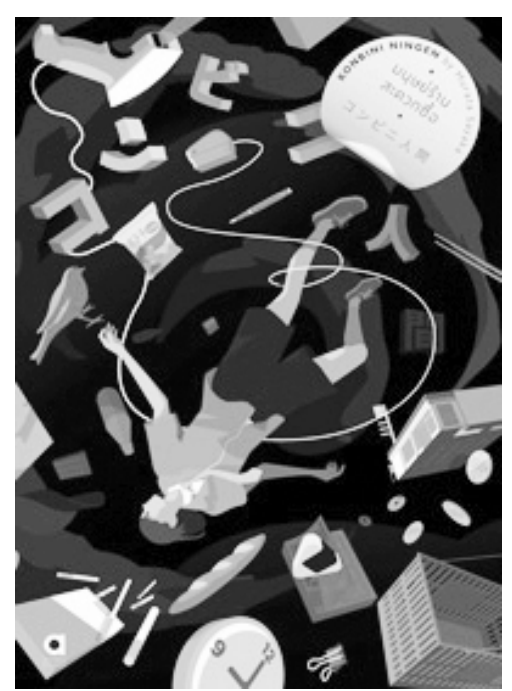

【図1】タイ語翻訳版の表紙

現在(2020年11月時点)出版されている、村田 紗耶香のタイ語翻訳の作品はこの作品のみであ る。タイ語翻訳版の出版社である animag ${ }^{6}$ 社への インタビューによると、『コンビニ人間』は芥川 賞を受賞し評価が結構高かったため、本作品を タイ語に翻訳することにしたとのことであっ た。タイで日本の現代小説が盛んに翻訳されて いる中、『コンビニ人間』の位置付けはどのよう なものなのか。ここで、タイ紀伊國屋書店の調 査による、2018年と2019年におけるタイ語に翻 訳された日本の小説のベストセラー本の一覧を 取り上げ、【表1】と【表2】で示す。

http://www.animagshop.com/product/689

【表1】ベストセラー本の一覽、その一(期間 : 2018/01/01 2018/12/31 $)^{7}$

\begin{tabular}{|c|l|l|}
\hline No. & \multicolumn{1}{|c|}{ 書名 } & \multicolumn{1}{|c|}{ 著者 } \\
\hline 1 & ナミヤ雑貨店の奇蹟 & 東野圭吾 \\
\hline 2 & また、同じ夢を見ていた & 住野よる \\
\hline 3 & コーヒーが冷めないうちに & 川俊和 \\
\hline 4 & コンビニ人間 & 村田紗耶香 \\
\hline 5 & カラフル & 森絵都 \\
\hline 6 & ぼくは明日. 昨日のきみとデート & 七隆文 \\
\hline 7 & 旅猫リポート & 有川浩 \\
\hline 8 & 未来のミライ & 細田守 \\
\hline 9 & あん & ドリアン助川 \\
\hline 10 & 君の膵臟をたベたい & 住野よる \\
\hline 11 & 彼女と彼女の猫 & 新海誠 \\
\hline 12 & 村上春樹、河合隼雄に会いにいく & 村上春樹、河合隼雄 \\
\hline 13 & 去年の冬、きみと別れ & 中村文則 \\
\hline 14 & 国境の南、太陽の西 & 村上春樹 \\
\hline 15 & 容疑者Xの献身 & 東野圭吾 \\
\hline 16 & 夜葬 & 最東対地 \\
\hline 17 & イニシエーション·ラブ & 乾くるみ \\
\hline 18 & Never Let Me Go & カズオ.イシグロ \\
\hline 19 & 螢·納屋を焼く·その他の短編 & 村上春樹 \\
\hline 20 & 黄金仮面 & 江戸川乱歩 \\
\hline
\end{tabular}

6 animag社の主なタイ語翻訳作品はライトノベルだが、小説を翻訳した経歴もある。例えば、新海誠氏の『ほ しのこえ』、『秒速5センチメートル』、『言の葉の庭』また、葦舟ナツ氏の『ひきこもりの弟だった』などで ある。

7 紀伊国屋書店タイ支店によるべストセラー本のランキングは30位までであったが、便宜上、本稿ではそこ から上位20位までを取り上げることとする。 
【表2】ベストセラー本の一覧、その二(期間 : 2019/01/01 - 2019/12/31)

\begin{tabular}{|c|l|l|}
\hline No. & \multicolumn{1}{|c|}{ 書名 } & 著者 \\
\hline 1 & ナミヤ雑貨店の奇蹟 & 東野圭吾 \\
\hline 2 & コーヒーが冷めないうちに & 川俊和 \\
\hline 3 & ときどき旅に出るカフェ & 近藤史恵 \\
\hline 4 & コンビニ人間 & 村田紗耶香 \\
\hline 5 & パンとスープとネコ日和 & 群ようこ \\
\hline 6 & 天気の子 & 新海誠 \\
\hline 7 & 言の葉の庭 & 新海誠 \\
\hline 8 & 国境の南、太陽の西 & 村上春樹 \\
\hline 9 & 秘密 & 東野圭吾 \\
\hline 10 & ノルウェイの森 & 村上春樹 \\
\hline 11 & イニシエーション・ラブ & 乾くるみ \\
\hline 12 & 手紙 & 東野圭吾 \\
\hline 13 & ぼくは明日、昨日のきみとデート & 七月隆文 \\
\hline 14 & 時給三○○円の死神 & 藤まる \\
\hline 15 & また、同じ夢を見ていた & 住野よる \\
\hline 16 & カッコウの卵は誰のもの & 東野圭吾 \\
\hline 17 & 秒速 5 センチメートル & 新海誠 \\
\hline 18 & 容疑者Xの献身 & 東野圭吾 \\
\hline 19 & 旅猫リポート 有川浩 \\
\hline 20 & 私のクラスの生徒が、一晚で24人死にました。 & 日向奈くらら \\
\hline
\end{tabular}

二つの表から、二年間連続でランキングを保ったのは、第一位、東野圭吾の『ナミヤ 雑貨店の奇蹟』と第四位、村田紗耶香『コンビニ人間』の二作であった。作品がこの二年間 でランキングにもっとも多く入った作家は言うまでもなく東野圭吾 ${ }^{8}$ である。タイの Facebookに「Higashino Keigo 神秘と奇跡」というファンクラブのグループがあること は、東野圭吾の高い人気を示す証であろう。村田紗耶香『コンビニ人間』は先に言及した 米国での売り上げの状況と比較してみると、タイでは売り上げが比較的高いといえる。 また、『コンビニ人間』が村田の唯一つのタイ語に翻訳された作品であるにもかかわら ず、タイで2018年10月に刊行されたことを考えると、本作品はタイ人読者の間で人気の 高い日本の翻訳小説の一つであると言えよう。

さて、このような人気の高い作品を一般のタイ人はどのように読むのかということ について触れてみたい。翻訳されたタイ語版の裏表紙を見ると、以下のように書いて

8 ランキングを入った作品を数えてみると、次のような結果が出た。（ちなみに、重なっている作品は数え ないことにした。最初の三名のみ注目とする。)1.東野圭吾(5作品) 2.新海誠と村上春樹はそれぞれ4作品で あった。

9 これは「Higashino Keigo ความลึกสบและความมหศจรรย」というタイ語から訳したものである。2020年11月現在約 1,600人のメンバーがいる。 
ある。

"ฟุรุคุระ เคโกะ หญิงสาวรยสามสิบหกซึงษงไมเตงงาน หลงสำเร็จการศึกษาจากมหาวิทยาสยก็ทำงานพิเศ ษฆี⿰ี丶านสะดวก 浔อเป็นเวลาสิบแปดปีโดยไมไดหางานทำ และจนถึงษดะเี็ยงไมมีแฟน อาหารทีเธอรบประทานใน เตตละนเป็นอาหารจาก㳊นสะดวถซือ เมะเตในความฝนก็ยงกดเครืองคิดเงินขอะรานสะดวกซือ ความสะอาดเรีย

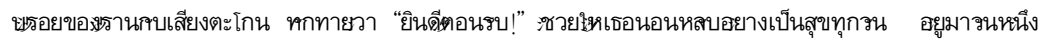
ชิราฮะ พนกงานหนุมหฬาใหมซึึง เฟ่าหมายหาคูเตงงานก็ปรากฏตว เขาพูดจาทิมแทงใจเธอ รวาการใชชชีวิตอ

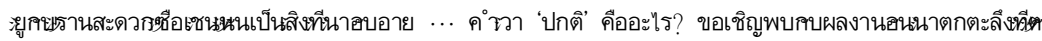
งคำถามเกียวกบการดำรงชีวิตในยุคษจจุษนอยางเรียบงาย"

上述したタイ語は「36歳未婚女性、古倉恵子。大学卒業後も就職せず、コンビニのバ イトは18年目。これまで彼氏なし。日々食べるのはコンビニ食、夢の中でもコンビニ のレジを打ち、清潔なコンビニの風景と『いらっしやいませ!』の掛け声が、毎日の安 らかな眠りをもたらしてくれる。ある日、婚活目的の新入り男性、白羽がやってきて、 そんなコンビニ的生き方は䎵ずかしいと突きつけられるが、…「普通」とは何か?現代 の実存を軽やかに問う衝撃作」という2016年に発表された『コンビニ人間』の単行本の帯 に書いてある文章がそのまま翻訳されたものである。この文章から、本作品に対する 「普通とは何?」や「現代の実存」を問うことが、一般のタイ人の読み方に影響を与えると 推測できる。インターネットやッイッター上で、一般のタイ人の読者は次のような感想 を綴っている。

・さすがに芥川龍之介賞を受賞した大傑作だ。

・作品を読んだら、二つの方向に行く。好きになってしまうか、あるいは嫌いに なってしまうかだ。

・恵子がやったことは理解できなくもない。恵子に共感できる場面もある。

・現代社会にふさわしい小説である。

・読んだ後、自分はどのような人間であるか、これからどのように生きて行くべ きか、いろいろと考えさせられる作品である。

・二人の登場人物 (古倉と白羽)は自分自身の独特の信念、価値観、生き方を持って いる。古倉は社会における多数の人々の生活パターンに従わない人間の代表で あると思う。だから、社会の規範によって「奇妙」だとか、「異常」だと判断され てしまったのかもしれない。だが、古倉は他人に迷惑をかけない人でもある。 古倉と白羽のみならず、作品全体における登場人物は現代社会(日本の社会だけ でなく)の人々を投影しているだろう。

・本作品を読むことによって、新しい言葉や、コンビニでの働くための規則を学 ぶことができた。作者は読者を古倉といら人物の理解に導いてくれる。彼女は 変わり者で、「異常」な人間だと見られてしまうことに彼女自身も悩みがある。 他人から「普通の人間」として認吼るように、古倉はいろいろ自分自身のこ とを変えようと努力している。「コンビニ」は古倉のコンフォートゾーンだ。古 
倉は常に同僚たちの行動を分析しようとし、彼らを模倣する。なぜなら、古倉 は「模倣」することによって、自分が他の人と同じような「普通の人間」になれる と考えているからである。だが、古倉より更に「異常」な白羽が新入りの店員と してコンビニに入ることによって、古倉の持っていた全ての自信が摇らいでし まった。『コンビニ人間』を読んでいる間、結局「普通」とは何かという疑問が ずっと頭の中に浮かんでいた。

・作者が社会のある価值観で判断された一人のことを語ることから、読者である 我々は皆が言っている「普通」とは何か、どのような基準で「普通」を決めるの か、あるいは我々の「普通」は他人の「普通」と同じようなものなのだろうかとい う疑問を感じるようになった。古倉は「もう年を取ったのに、どうしてまだコ ンビニで働いているの?」「どうして就職をしないの?」「彼氏ができたの?」「どう してまだ結婚していないの?」と度々聞かれていた。定職を持たず結婚のことを 考えていないことは彼女を「社会の異物」にしてしまう。自分の生き方がなぜ 「異常」なのか、他人を不安がらせるか、古倉は理解できない。なぜ自分の生き 方なのに他人によって善し悪しを決められるのか。古倉は自分が何を望むか、 どのような生き方を選択したいかということを明確に知っている一方、古倉 に疑問を投げ、彼女の行動と生き方を判断する人たちは自分の望みすらまだ把 握できないかもしれない。結局、古倉という主人公の決断によって、我々が 生きている社会における「善し悪し」、「正常と異常」、「内と外」という様々な定 義を決めた人は自分自身なのか、あるいは他人なのかという疑問に気づかさ れた。

これら一般のタイ人読者の感想から、本作品は比較的好評を得たことが分かる。ま た、日本国内での本作品に対する評価、先行研究の見解と方向性が近いものであったと いえよう。現代社会に相応しい小説でもあり、国の別なくどこでも起こり得ることなの で、国境を越えて、現代社会に生きている誰でもが共感できるのであろう。

\section{3 タイ語翻訳について}

本作品を翻訳する過程の中でどのような問題に直面したか、または気になる部分が あるのかなど、翻訳家であるパンウィモン氏にインタビューで質問したところ、次の ように答えてくれた。「一番問題になったのはたぶん日本語の固有の言葉だったでしょ う。例えば、料理名や、日本にしかないものなどですね。日本に行ったことがあり、 または日本に滞在したことがあるタイ人なら、何となく想像できるでしょう。逆に、 全くそういう経験のない人なら、想像できないのではないでしょうか。こういう時に は、どのように説明すればいいのか、そのまま直接翻訳するかあるいは注釈を加えた ほうがいいのかと、時々迷うこともありました」パンウィモン氏の回答から、『コンビ 二人間』を翻訳するには、「料理名」、「日本にしかないもの」という日本語の固有の言葉 
についての翻訳の問題が浮き彫りになってきた。ここで篠原有子氏 (2013)の論文を参照 しながら、本作品におけるタイ語訳について考察を行っていきたい。篠原氏はペダーセ ン氏 ${ }^{10}$ の見解に言及し、「言語外文化関連記(Extralinguistic Cultural References)」をECR とし、「文化固有項目 (Culture-Specific Items)」をCSIとした上で、このような異文化要素 (ECR/CSI) はどのような言葉を指すのか、異文化要素を12領域に分けて説明している。 下の表3に示す。下の表3は篠原氏の言葉の表をもとに論者が作成したものである。

【表3】ペダーセン氏の異文化要素の分類

\begin{tabular}{|l|l|}
\hline 1. 度量衡 & 7. 娛楽 (Coney Island など) \\
\hline 2. 固有名詞(人名、地名、制度上の名称、商標) & 8. 教育 (college degrees など) \\
\hline 3. 職業上の役職名(Detective Sergeant など) & 9. スポーツ (the pitcher mound など) \\
\hline 4. 料理および酒類 & 10. 通貨 \\
\hline 5. 文学 & 11. 技工物 (例 double Alberti feedback loop) \\
\hline 6. 政府 (the Foreign Office など) & 12. その他 \\
\hline
\end{tabular}

先程取り上げたパンウィモン氏の返答の中、作品を翻訳するには「料理名」、「日本に しかないもの」などという日本語の固有の言葉の翻訳に若干問題あると述べられている ため、本論では、『コンビニ人間』における日本語の固有の言葉の翻訳に焦点を当て、ど のような翻訳方略が採用され、そして、その翻訳を通して作品への理解、読みにどのよ うな影響を与えるのかをめぐって分析してみたい。

本作品に出てくる日本語の固有の言葉を整理してみると、料理名と日本にしかないも のあるいは言葉という二つのグループに分類できる。以下作品の引用は【表 $3 】$゙】゙の 項目に当てはまるか、引用文の後ろに【表3】で使用した数字を付けることにする。ま た、篠原氏の論文ではペダーセン氏の異文化要素の翻訳方略が採用されたが、篠原氏の 論文は映画の字幕の異文化要素の方略を中心として論じており、注釈の付加が不可能な 映画の字幕であるため、文学作品の異文化要素の翻訳方略とはやや差が生じるはずであ る。本稿では篠原氏が使用したペダーセン氏の翻訳方略の中から、本作品に当てはまる 方略のみ採用したい。とりわけ、ペダーセン氏の翻訳方略を適用した本作品における 「詳述」という方略を簡単に示しておきたい。篠原氏によると、「詳述」の方略は、「詳述 とは、翻訳されない形で提示された異文化要素に情報を付け加える方略で、完成 (completion)あるいは付加(addition)という手法を通して行われる(Pedersen, 2011： 79-82)。」と説明されている。さて、まず本作品における日本料理名の翻訳について見 ていきたい。

10 Pedersen, J. (2011). Subtitling norms for television. Amsterdam \& Philadelphia : John Benjamins. 
【表4】『コンビニ人間』における料理名の翻訳方略

\begin{tabular}{|c|c|c|}
\hline 起点テクスト (ST) & 目標テクスト(TT) & 翻訳方略 \\
\hline $\begin{array}{l}\text { ・「私は、父と母とまだ小さい妹が、喜 } \\
\text { んで小鳥を食べているところしか想像 } \\
\text { できなかった。父は焼き鳥が好きだ } \\
\text { し、私と妹は唐揚げが大好きだ。」(4) }\end{array}$ & 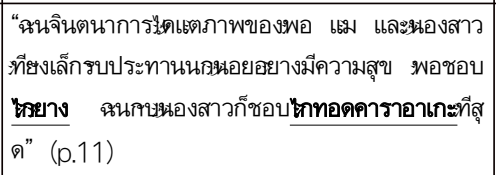 & 直接訳、詳述 \\
\hline $\begin{array}{l}\text { ・私は機械が作った清潔な食べ物を整 } \\
\text { 然と並べていく。新商品の明太子 } \\
\text { チーズは真中に二列に、その横には } \\
\text { お店で一番売れているッナマヨネー } \\
\text { ズを二列に、あまり売れないおかか } \\
\text { のおにぎりは端っこだ。」(4)(p.9) }\end{array}$ & 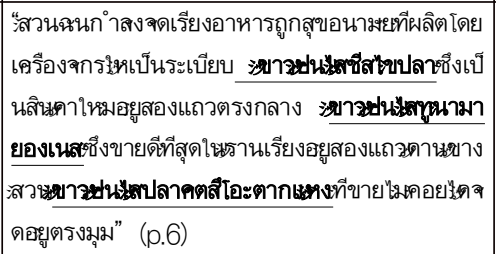 & $\begin{array}{l}\text { 詳述、詳述、直 } \\
\text { 接訳 }\end{array}$ \\
\hline $\begin{array}{l}\text { • 「じゃあ、10時ごろちょっと両替行 } \\
\text { くねー。あ、それと、今日、予約の } \\
\text { いなりずしがあるから、お客様が来 } \\
\text { たら対応よろしくね。」(4) (p.7) }\end{array}$ & 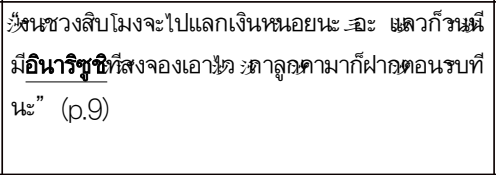 & 音訳 (+ 注釈) \\
\hline $\begin{array}{l}\text { ・「(略)客が買うかどうか㥗んでいるよ } \\
\text { うに見えるときは、一歩引いて待つ } \\
\text { ことにしている。」「それと、アメリ } \\
\text { カンドッグ」(4) (p.5) }\end{array}$ & 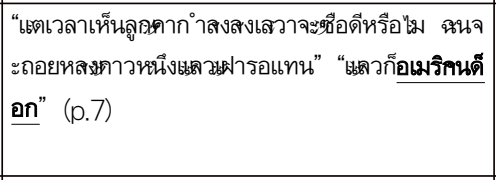 & 音訳 (+ 注勫) \\
\hline $\begin{array}{l}\text { ・「暑い日はサンドイッチが売れ、寒 } \\
\text { い日はおにぎりや中華まん、パンが } \\
\text { よく売れる。」(4) (p.24) }\end{array}$ & 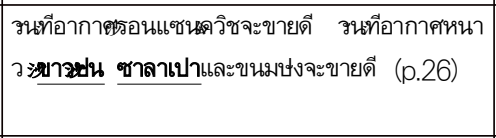 & 直接訳 \\
\hline $\begin{array}{l}\text { ・「あと、今日はフランクがセールだ } \\
\text { から、いっぱい仕込んで！」(4) } \\
\text { (p.44) }\end{array}$ & 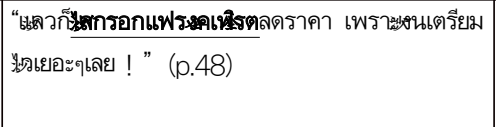 & 詳述 \\
\hline $\begin{array}{l}\text { •「(略)手の甲には三日前にコロッケを } \\
\text { 揚げたときの火傷のあとが微かに } \\
\text { 残っている。」(4) (p.137) }\end{array}$ & $\begin{array}{l}\text { หลงมือมีรอยแผลโดนลวกจางๆ ตอนทีทอดคร็อกเกะ } \\
\text { เมือวามรนกอน }(p .137)\end{array}$ & 音訳 \\
\hline $\begin{array}{l}\text { ・「白羽さんが解凍したおかずは、シュ } \\
\text { ウマイとチキンンナゲットだった。」(4) } \\
\text { (p.143) }\end{array}$ & $\begin{array}{l}\text { คษฆาวทีคุณชิราฮะนำไปละลายณำแข็งคือขนมจีบศ } \\
\text { บหกเก็ตะก (p.143) }\end{array}$ & 直接訳、直接訳 \\
\hline $\begin{array}{l}\text { •「それなのにパスタが焼きそばやお } \\
\text { 好み焼きと混ざって置いてあり、 } \\
\text { ちっとも目立っていない。」(4) } \\
\text { (p.145) }\end{array}$ & $\begin{array}{l}\text { 洚งทีเป็นแบษสนแตพาสตากลบวางปะปนคบยากิโซ } \\
\frac{\text { บะและโอโคโนะมิยากิ }}{\text { (p.145) }} \quad \text { ทำใหไมสะดุดตาเลยซกนิด }\end{array}$ & 音訳 \\
\hline $\begin{array}{l}\text { ・「(略)社員なのだろうと納得した様子 } \\
\text { で、奇麗に並べ終えたばかりの明太 } \\
\text { 子パスタをとっていた。」(4) (p.145) }\end{array}$ & $\begin{array}{l}\text { อีกฝายก็หยิบพาสตาไขปลาที่เพิงจดเรียงฮยางงดงาม } \\
\text { จนเสร็จดวยทาทางเหมือนเฉาใจวาฉนคงเป็นพพะกงา } \\
\text { นประจำ (p.146) }\end{array}$ & 直接訳 \\
\hline $\begin{array}{l}\text { ・「あ、女性客が多いので、春雨スー } \\
\text { プがもっと種類があるといいです } \\
\text { ね。」(4) (p.148) }\end{array}$ & 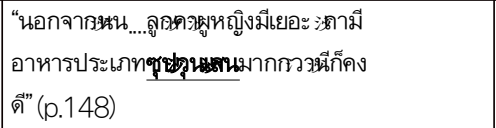 & 直接訳 \\
\hline
\end{tabular}

11 本文の引用は村田紗耶香『コンビニ人間』(文藝春秋, 2016)に拠る。 
以上の【表4】から日本料理名に関する『コンビニ人間』における異文化要素の翻訳方 略は次のようにまとめられる。直接訳の方略が採用されたのは「焼き鳥」、「おかかのお にぎり」、「おにぎり」、「中華まん」、「シュウマイ、」「チキンナゲット」、「明太子パス タ」と「春雨スープ」という言葉である。「いなりずし」「「アメリカンドッグ」の場合は 音訳を用いた上で、ページの下の部分に注釈が加えられている。特に、「アメリカン ドッグ」では、似たようなタイのおかしの例を取り上げ、比較させながら、本物を見た ことがないタイ人の読者でも「アメリカンドッグ」が想像しやすいように注釈がされて いる。

また、詳述方略を使用したのは、「唐揚げ」、「明太子チーズ」、「ツナマヨネーズ」、 「フランク」である。「唐揚げ」を翻訳するには“切均”(フライドチキン)という言葉を付 加しても訳出したタイ語の言葉には支障がなかった。「明太子チーズ」と「ツナマヨネー ズ」には両方澡羽น”(おにぎり)という言葉を付加することにした。これはタイ語に訳す 時、既に涗า将ん”(おにぎり)という言葉が含まれる「おかかのおにぎり」とは翻訳が異な るためである。「フランク」の場合、“㽝的的”(ソーセージ)という言葉を付加した。この ように、言葉を付け加えるこ とによって、具体的にその料 理がどのようなものか、日本 文化にあまり親しみのない夕 イ人の読者でも理解しやすく なる。

次に日本特有のもの、ある いは日本語の固有の言葉の翻 訳方略を検討してみたい。

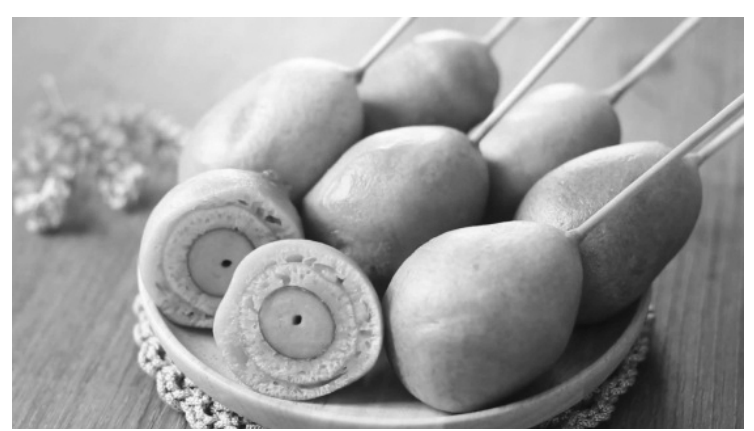

【図2】「ポーンネン」というタイのお菓子

https://www.pinterest.com/pin/218143175689054002/

【表5】『コンビニ人間』における日本語の固有の言葉の翻訳方略

\begin{tabular}{|c|c|c|}
\hline 起点テクスト (ST) & 目標テクスト(TT) & 翻訳方略 \\
\hline ・「支払い、スイカで。」(10) (p.5) & "จายศดวยษตรซุยกะ" (p.8) & 詳述 (+注釈) \\
\hline $\begin{array}{l}\text { ・大学に入ったばかりの頃、学校の行 } \\
\text { 事で能を観に行き、友達がいなかっ } \\
\text { た私は一人で帰るうちに道を間違え } \\
\text { たらしく、(略)。」(7) (p.14) }\end{array}$ & $\begin{array}{l}\text { “ชวงเฉามหาวิทยาสยใหมๆ ฉนไปดูละครโนม ในงา } \\
\text { นกิจกรรมของโรงเรียน ระหวางเดินทางกลบเพียงล } \\
\text { ำพงเพราไมมีเพือน ก็ดูเหมือนวาฉนจะจำทางผิด” } \\
\text { (p.16) }\end{array}$ & 詳述 (+ 注䣋) \\
\hline $\begin{array}{l}\text { - 「自分と同じ大学生くらいの女の子 } \\
\text { や、フリーター風の男の子に、少し } \\
\text { 年上の主婦と思われる女性、(略)。」 } \\
\text { (3) (p.15) }\end{array}$ & $\begin{array}{l}\text { "หงเด็กสาวดูเหมือนหกศึกษามหาวิทยาลยคจายคบฉ } \\
\text { น เด็กหนุมที่เหมือนจะเป็นฟรีเตอะ และหญิงสาวอ } \\
\text { ายุมากกวาเล็กษอยทีคิดวานาจะเป็นแมะ } \\
\text { (p.18) }\end{array}$ & 音訳 (+ 注釈) \\
\hline
\end{tabular}




\begin{tabular}{|c|c|c|}
\hline 起点テクスト (ST) & 目標テクスト(TT) & 翻訳方略 \\
\hline $\begin{array}{l}\text { ・「私はバックルームで見せられた見 } \\
\text { 本のビデオや、トレーナーの見せて } \\
\text { くれるお手本の真似をするのが得意 } \\
\text { だった。」(12) (p.16) }\end{array}$ & $\begin{array}{l}\text { “ฉนถนดการเลียนแบบจากวีดีโอตวอยางที่ใดดูในแบ์ } \\
\text { ครูม และตวอยางหีผูฝึกสอนทำใหดู" }(p .19)\end{array}$ & 音訳 (+ 注釈) \\
\hline $\begin{array}{l}\text { •「いつも家に帰るとすぐに、狭い六畳 } \\
\text { 半の敷きっぱなしの布団の上に身体 } \\
\text { を横たえる。」(1) (p.16) }\end{array}$ & 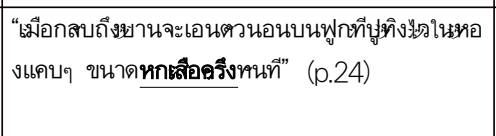 & 直訳 (+ 注釈) \\
\hline $\begin{array}{l}\text { ・「まあまあ、まだ習うことはいっぱ } \\
\text { いあるよ一!じゃあ古倉さん、フェイ } \\
\text { スアップからよろしく! 俺もあがっ } \\
\text { て今日は寝るわ一。」(2) (p.47) }\end{array}$ & 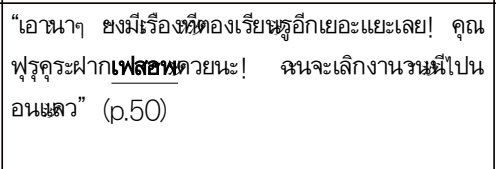 & 音訳 (+ 注䣋) \\
\hline $\begin{array}{l}\text { ・「だって、縄文時代からそうじゃな } \\
\text { いですか。」(2) (p.49) }\end{array}$ & 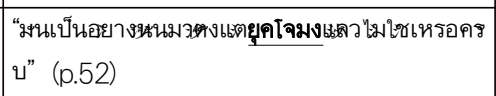 & 直訳 (+ 注勫) \\
\hline $\begin{array}{l}\text { ・「ウォークインから在庫を出して白羽 } \\
\text { さんに在庫を並べる説明をすると、 } \\
\text { 私は急いで自分の仕事に戻った。」(2) } \\
\text { (p.49-50) }\end{array}$ & 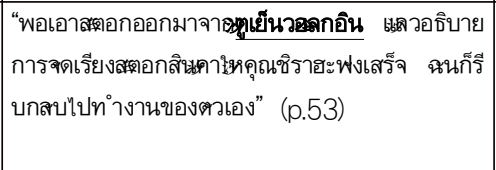 & 詳述 (+ 注勫) \\
\hline $\begin{array}{l}\text { ・「(略)私は小さい頃あそんだ影送りを } \\
\text { 思い出して、目をこすった。」(7) } \\
\text { (p.80) }\end{array}$ & $\begin{array}{l}\text { "ฉนนึกถึงการเลนคาเงะโอคุริ ที่เคยเลนเมือสมยยยงเล็ } \\
\text { กแผวขขยีตา" (p.82) }\end{array}$ & 音訳 (+ 注瀵) \\
\hline
\end{tabular}

以上の【表5】から見られるように、音訳が圧倒的に適用されている。また、注目す べきは、ここでかなり詳述方略も採用されていることである。例えば、「スイカ」には“ษ ตร”(カード)、「能には“ละคร”(ドラマ)、「ウォークイン」には海เย็น”(冷蔵庫)という言葉が 付加されている。だが、料理名の翻訳と同じような単一な言葉を付加しても、タイ人に は想像し難いため、注釈も付け加えられた。【表4】と【表5】を䌆めて分析してみる と、次のような結果が明らかになる。本作品全体における異文化要素の翻訳方略につい ては、直接訳、音訳と詳述という方略が採られた。「焼き鳥」のような、タイに同じよう な種類の料理がある場合は直接訳が採用された。料理名の翻訳を詳述の方略で済ませる のは、日本料理がタイで比較的に認知度が高いと判断されたためであろう。一方、日本 特有のもの、日本の固有な言葉の場合、音訳、詳述の方略の回数が直接訳を上回ってい る。これは本作品の異文化要素の翻訳志向は起点志向に傾いていることの表れであり、 作品内の日本文化の雾囲気を保ちながら、タイ人の読者が作品や日本文化をより一層理 解することに繋がるだろう。

最後に、単語のレベルのみならず、作品に出てくる日本の固有な挨拶表現の翻訳を一 つの例として取り上げたい。これは変なお客さんが店に入って他の客を一々と注意し、 古倉が迅速に対応して終わった場面である。ここは店長と泉という登場人物との会話を みたい。 
ST「じやあ俺、あがるわ一。今日も夜勤だし」

「お疲れさまです一。あ、そうそう、店長、白羽さん、今度注意してもらえ ますか?

あの人、サボり癖があって、私が言っても駄目なんですよ一」(p.59)

TT 澫นฉนเลิกกอนนะ วนมีทำกะกลางคืนเหมือนเดิม"

"เหนือยหนอยนะดา จะ จริงฐดวฆผูจดการ คราวหะาชวยตกเตือนคุณชิราฮะไดไหมคะ คนคนษนชอ บโดดงาน ฉนพูดอะไรไปก็เปลาประโย

タイ語では日本語のように、「お疲れさまでした」や「で苦労さまでした」という特別 の挨拶表現がなく、仕事が終わる時など、相手に感謝の気持ちを表わすため、タイ人は 代わりに「ありがとうございます」という表現を使う。上の文の下線部分「お疲れさまで す」は、タイ語の訳出ではぺダーセン氏が提示した「置き換え」という翻訳方略により「疲 れましたね」という表現が使われた。もともと、タイは仕事をしてくれる人に対して、 「お疲れさまでした」という表現を使う習慣がないので、ここで直接訳すれば不自然な夕 イ語になってしまうだろう。つまり、それではこれはタイの社会背景に合わせ、ここ の異文化要素の翻訳志向は目標志向になってしまうわけである。

\section{4 本作品に対するタイ人日本語学習者の読み方}

第二章では、本作品に対する一般のタイ人読者の読み、感想などを紹介したが、本章 では「普通を問う作品」以外、タイ人の日本語学習者は本作品を通してどのように日本文 化を受容するのかということに触れてみたい。対象者はタマサート大学の院生4名で、 日本語能力の内訳はN2が3名、N1が1名である。全員が日本に行った経験あるいは滞在 した経験がある。3名は現在日本に関する仕事、とりわけ日本人に接触する機会が多い 通訳者をしている人達である。これらの4名は日本語版と夕イ語訳版両方を読んだ。本 作品に対する学習者の主な意見、興味を本作品日本語版からの引用を交え、以下のよう に分類する。

\section{(1) 日本の働く様式と文化}

コンビニで㗢いているのは、アルバイトとしての仕事だが、ある程度日本人の働く 価值観を反映している。作品全体では、コンビニの厳しい規則の下で働かなければなら ないことや、コンビニのため貢献すべき店員の姿が古倉という登場人物を通して描かれ ている。コンビニにおいて割り当てられた役割があり、それぞれの店員に委ねるシス テムがある。

各店員は、その規制を順守し、コンビニが期待する質の高い店員になろうとしてい 
る。全員が同じ方向に行動すると、連帯感が生まれる。店員がうまく仕事すれば、コン ビニ作業のシステムを安定させるほか、コンビニの高い売り上げにも繋がる。つま り、店員の能力は直接コンビニの運営に影響を与えるといえる。

「私たちは、お客様に最高のサービスをお届けし、地域のお客様に愛され、選ば られるお店を目指していくことを誓います!」(p.45)

上の引用は、自分の所属している機関、あるいは国を重要視する日本社会の概念を反 映している。その機関の一員あるいはその国の国民として皆が献身的に力を尽くすべき である。従って、そのような連帯感を維持するため、社会の規範の中で皆が同じような 行動を取らなければならなくなる。「出る杭は打たれる」という諺のように、規範外の ようなことをしてしまったら、日本人にとってよくないことになるだろう。このよう な状態を保つため、度々自分が考えていること、したいことは社会では許されない。 これは連帯感を重視する日本人の価值観の一様性を反映し、つまるところコンビニは日 本の社会を投影しているといえるのではないか。

\section{(2) 日本社会におけるジェンダー}

まず、日本の社会における男女の役割についての意見を取り上げたい。作品中の「男 なら㗢け、結婚しろ、結婚したらもっと稼げ、子供を作れ」(pp.100-101)から、現代社 会になっても「男性は外で働く、女性は家で家事をする」という概念はまだ根強く日本の 社会に固定しているように見られる。そのようなわけで、30代にもなり結婚もせずに アルバイトを続ける古倉が周囲に奇妙に見られるのは当然なことである。これは以下の 引用から闡明に描出されている。

「二十代前半のころは、フリーターなど珍しいものではなかったので特に言い訳 は必要がなかったが、就職か結婚という形でほとんどだが、社会と接触していき、 今では両方ともしていないのは私しかない」(pp.35-36)

以上のような女性の役割が社会から期待されていることが作品に反映されている反 面、男女のジェンダー的固定観念を破壊しようとする部分もある。大切なのは自分と異 なっても他人のアイデンティティーを認めることであるという意見も出た。

「白羽さん、今は現代ですよ!コンビ二社員はみんな男でも女でもなく店員です! あ、バックルームに在庫があるんで、それを並べる仕事も一緒覚えちやいましょう!」 (p.49) 
また、この点について、ある学習者は人間の価値観といえば、性別によるものでは なく、仕事の成果から判断すべきだという意見を付け加えた。上述したことの他、性的 ダイバーシティが認められるようになってくる現象も描写されていることを本作品か ら読み取る学習者もいた。例えば、以下のような部分である。

「あのさ、私けっこう同性愛の友達とかもいるしさあ、理解あるほうだから。今 はアクセシャル?とかいうのもあるんだよね。」(p.37)

これは「Diversity \& Inclusion Know Differences, Show Differences. ちがいを知り、 ちがいを示す。」というTOKYO OLYMPICS 20200アクションワードであり、ジェン ダー・ダイバーシティが認められるようになってきていることを表わす一つの例であ るといえるだろう。このようなことは前の文学作品にはあまり見られなかったが、日 本が徐々にジェンダーに関する姿勢を改善していく方向にあることが分かる。しかし ながら、「女というだけで寄生虫ということを許されている奴等に」(p.115) とあるよう に、性差別という概念は日本の社会にまだ残っていることは否定できないだろう。伝統 的な習慣に強く執着してきた日本であるため、保守的な価值観を持つ人も少なくなく、 自分と異なる考え方をまだ認められない人も多数であろう。

\section{(3)「コンビニ」の文化}

日本のコンビ二業界はかなり規模が大きいようである。様々な食べ物のみならず、 消費生活商品に至るまで備わっているため、お客さんにとって便利なところである。夕 イのような「屋台」文化がない日本では、コンビニが必要不可欠な場所であろう。自炊ま たはレストランで食事をしないなら、コンビニは食事を調達するための一つの良い選 択肢になる。日本の各コンビニメーカーでは、客のために質の高い商品を提供するため に激しい販売競争が行われている。日本のコンビニは商品を販売するばかりではなく、 いろいろなサービスを提供していることも周知である。また、コンビニでの仕事はア ルバイトとして雇用されているものの、ここからの収入は大学生、主婦などにとって 生活ができる一つの手段となり得るのではないか。

以上の三項目以外、フリーターの数の増加や、晚婚、超少子化の問題を表わす作品で あるという意見も出た。異文化の視点で作品を読んだタイ人学習者からは、本作品が 「普通を問う」作品であるということの他に、別の観点をも捉えていたことが見て取れ た。『コンビニ人間』は正に日本現代社会を反映し、日本の直面している深刻な問題を表 わしているだろう。 


\section{5 まとめ}

本稿では村田沙耶香『コンビニ人間』のタイ語翻訳と文化の受容について明らかにし てきた。本作品はタイでも人気が高く、作品のテーマに対してもタイ人読者は理解ま たは共感できると言えよう。そして、本作品における日本料理名、日本の固有のもの という異文化要素の翻訳方略について分析した。直接訳、音訳と詳述という方略が最も 多く採用されたことが分かった。特に、料理名の翻訳を詳述の方略で済ませるのは、 日本料理がタイで比較的認知度が高いと判断されたためであろう。また、全体の翻訳志 向は起点志向の傾向があり、様々な注釈を付加することによって、作品内の日本文化の 雾囲気を保ちながら、タイ人の読者がより一層日本文化を理解できるような方略が採ら れていた。

更に、日本文化にある程度親しみのある日本語学習者の読者の、本作品に対する文化 の受容についても触れた。一般のタイ人読者と異なり、日本語学習者の読者は別の観点 を提示した。本作品は「普通とは何か」を問う作品のみならず、様々な日本現代社会問題 を反映している小説でもある。村田紗耶香の抜群な文体を鑑賞しながら、彼女が巧みに 描出した日本社会、あるいは日本文化を理解する傑作といえるだろう。

\section{参考文献(Bibliography)}

村田紗耶香 (2016)『コンビ二人間』, 東京：文藝春秋. Murata, Sayaka(2016) Convenience Store Woman. Tokyo : Bungeishunjū.

村田紗耶香 (2018)『コンビニ人間』, 東京：文藝春秋. Murata. Sayaka(2018) Convenience Store Woman. Tokyo : Bungeishunjū.

飯田祐子 (2019)「村田紗耶香とジェンダー・クイア一『コンビ二人間』、地球星人』、その他の創作」『超域的日 本文化研究』第10号, p.48. İda, Yuko(2019) Murata Sayaka, Genderqueer, Non-human, Convenience Store Woman. Earthian, JunCture Vol. 10, p.48.

篠原有子 (2013)「映画『おくりびと』の英語字幕における異文化要素 (日本的有標性)の翻訳方略に関する考察」 『翻訳研究への招待』第9号, p.81. Shinohara. Yuko(2019) A Study of Strategies for Translating CultureSpecific Items in the English Subtitles of the film Departures. Invitation to Translation Studies Vol. 9. p.81.

橋本夏希 (2019)「村田紗耶香『コンビニ人間』論一「普通」と「異常」の間で一」『藻』第53号, p.46. Hashimoto, Natsuki (2019) Murata Sayaka. Konbininingen Ron Futsū to ljō no aida de. Tamamo Vol. 53, p.46. 文藝春秋(2016)「我らコンビ二出身作家」『文學界』9月号, p.14. Bungeishunju Ltd. (2016) Warera Konbini shusshin sakka. Bungakukai Vol. September, p.14.

矢野千晶(2017)「差の消滅一村田紗耶香「授乳」から「コンビニ人間」まで一」『同志社女子大学日本語日本文学』 第29号. p.121. Yano, Chiaki(2017) Sa no shōmetsu Murata Sayaka Junyū kara Konbininingen made. Dōshishajoshidaigaku NihongoNihonbungaku Vol. 29. p.121. 


\section{インターネット}

Katy Waldman. (2018.12.4) The Best Books of 2018. Access date : 2020.11.5.

〈https://unw.newyorker.com/culture/2018-in-review/the-best-books-of-2018〉

Nithisa.L. (2020.1.11) Murata Sayaka Convenience Store Woman Book Review. Access date : 2020.11.6. 〈https://medium.com/a-reader)

P.LB.. 2016年8月11日. 芥川賞のすべてのようなもの. 2020年11月2日閲覽。P.LB. (2016.8.11) Like All of Akutagawa Ryunosuke Prize. Access date : 2020.11.2.

〈https://prizesworld.com/akutagawa/senpyo/senpyo155.htm〉

横山芙美. 2018年12月18日. 村田沙耶香の小説『コンビ二人間』が、米雑誌『ザ・ニューヨーカー』が選ぶ「The Best Books of 2018」に選出！。2020年11月5日閲覽。Yokoyama. Fumi. (2018.12.18) BOOK： CONVENENCE STORE WOMAN BY SAYAKA MURATA. 〈https://unw.gajapan.jp/culture/bma/20181218/sayaka-murata)

渡辺由佳里. 2018年7月19日. 英語圈ではわかりにくい『コンビニ人間』の日本的背景. 2020年11月5日閲覽。 Yukari.Watanabe. (2018.7.19) Eigokendewa wakrinikui Convenience Store Woman no nihonteki haikei. Access date : 2020.11.5.

〈https://unw.newsweekjapan.jp/watanabe/2018/07/post-48.php〉

\section{インタビュー}

Sirisereewan. Chanida. 著者によるインタービュ、バンコクにて. 2020年11月6日.

Sirisereewan. Chanida. An Interview at Bangkok, 2020.11.6.

Japanese Book Section - Kinokuniya Book Store (Thailand) Co.. Ltd. 著者によるインタービュ、バンコク にて, 2020年10月9日.

Japanese Book Section - Kinokuniya Book Store (Thailand) Co.. Ltd. An Interview at Bangkok, 2020.10.9. Jitrawiriyagul, Panvimol. 著者によるインタービュ、バンコクにて, 2020年10月19日.

Jitrawiriyagul, Panvimol. An Interview at Bangkok. 2020.10.19. 